\title{
Backplane Device
}

National Cancer Institute

\section{Source}

National Cancer Institute. Backplane Device. NCI Thesaurus. Code C49832.

A circuit board with connectors into which other cards are plugged. 